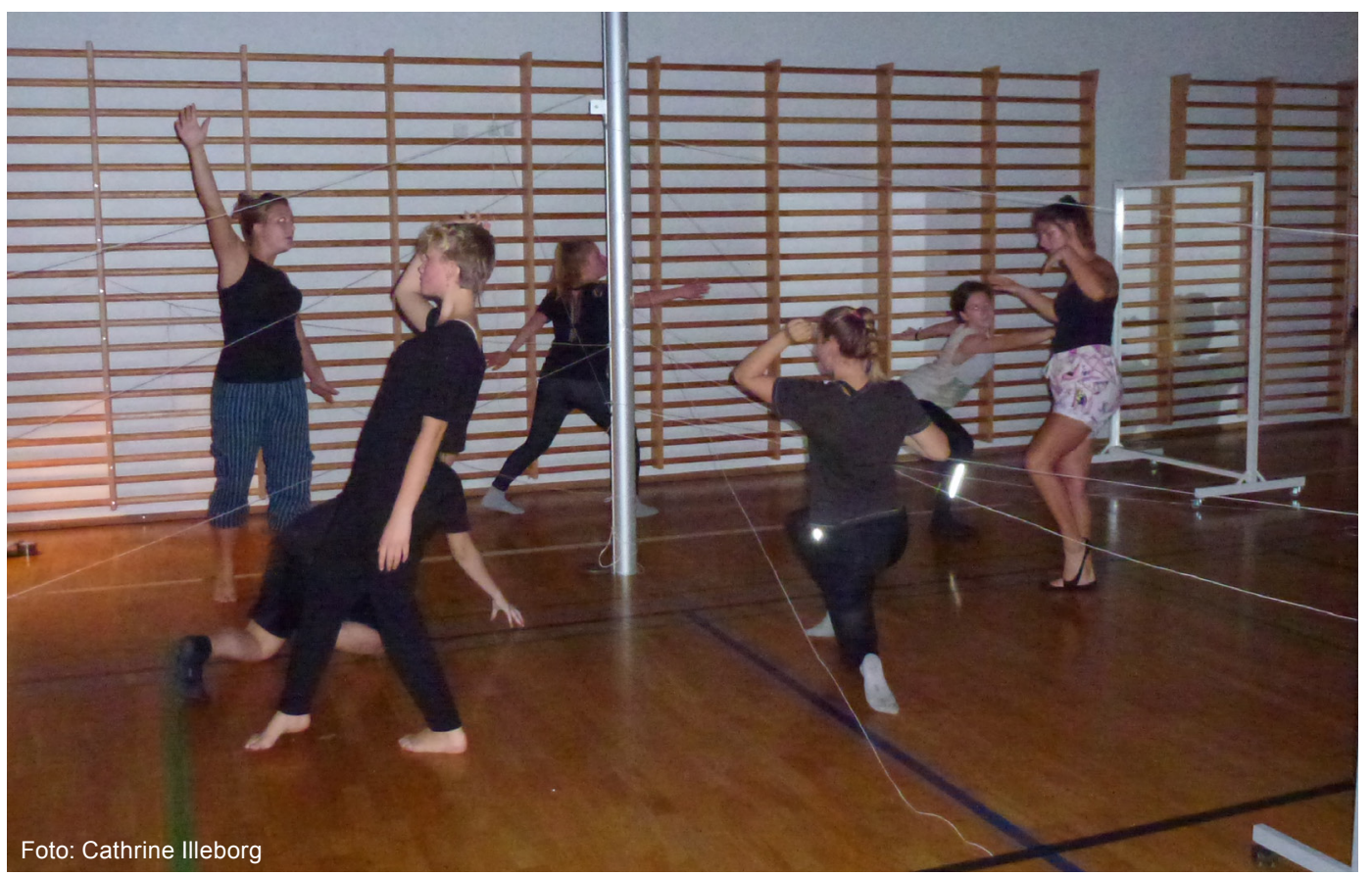

\title{
Et essay om udvikling og indvikling
}

\author{
CATHRINE ILLEBORG
}

Nøgleord: vejvisning i faglig progression, idrætsfaglige kompetencer, de svageste elever, idræt i gymnasiet, læringspotentiale.

Dette essay kobler sig konkret til UVM-rapporten "Progression - elevernes faglige udvikling i idræt" (Eriksen, Schiørring, Illeborg, november 2015). Essayet vil på den ene side problematisere konsekvenser af manglende eller tilfældig progression og på den anden side den udfordring idrætslærere står midt i, når de skal lave 3-årsplan og planlægge faglig progression i undervisningen. Idrætslæreren skal acceptere den præmis, at progressionsplanlægning særligt kommer de svageste elever til gode, fordi progressionstanken bygger på gentagelsesprincippet. Der lægges op til nytænkning af idrætsundervisningen på planlægningsniveau! Og der vises vej ind i progressionsjunglen. Essayet diskuterer de 2 konkrete hjælpeværktøjer: kompetenceplan og idrætstaksonomi. Og dette serveres i en tid, hvor idrætslæreren står over for udfordringer, fordi fagets status er under pres i gymnasieskolen. På den positive side indføres eksamen på idræt C og på den negative side mister faget status som studieretningsfags - og faget skal ikke være obligatorisk på HF. Der er store omvæltninger på vej. 

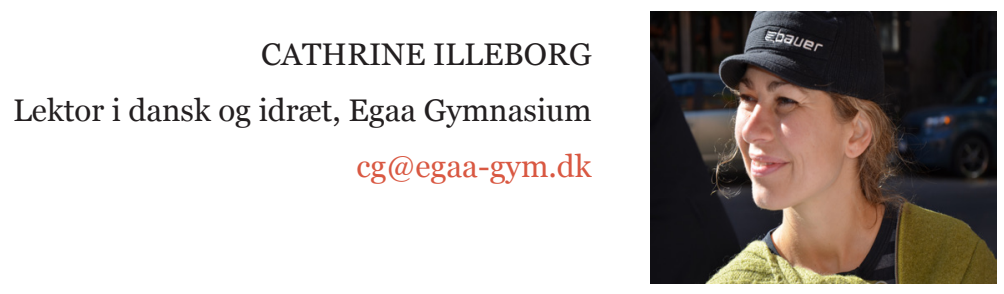

\section{OM ET ESSAY}

Et essay er en afprøvende og personligt reflekterende stiløvelse.

Stiløvelser dyrker sin egen stil.

Essayet vil helst bugte sig mellem det abstrakte niveau og det hvinende konkrete.

Et essay insisterer på at stille spørgsmål.

Det søger at få læseren hvirvlet med i en filosoferende tankerække.

Essayet afviser normen om smuk finale i endegyldig konklusion.

Essays er selvfede.

Karakteristik1.0 Hvad er vi for nogen? Sidder i idrætslærermøde med mine kolleger. Der bliver grinet, tænkt tanker om fremtidige projekter, idrætsdagen evalueres, skal vi købe nye bolde eller nye discs? Vi spiser kage og slutter med en kold øl. Vi rykker på ting i vores fag på skolen, og vi kan rigtig godt lide at arbejde sammen. Karaktertræk for vores gruppe er handlekraft, tolerance, holdånd og livsglæde. Vi kan lide mad, bevægelse af næsten alle slags, elever og det at udrette noget med eleverne. Vi er gode til at dele og stjæle fra hinanden. Vi er sjældent helt enige - men vi går efter konsensus. Vi er forskellige og har forskellige indgange i vores fag. Vores tilgang til undervisning i idræt er dog seriøs og forbundet med refleksion. Vi er også historikere, matematikere, biologer, litterater, fysikere, forfattere, opfindere, udviklere eller både og. Karakteristisk for vores møder er, at vi klør på med krum hals med en tung dagsorden og alt for kort tid. Punkter kan godt blive overfladisk behandlet nogle gange, fordi vi er så mange, der har hver vores input, men vi arbejder videre med tanker og handling hver for sig. Vi er en gruppe, der godt gider det hele. "Det kører sgu for os", tænker jeg.

Udfordring1.0 At sige ja. April 2015. Bliver ringet op af fagkonsulenten i idræt (Peter Mads Olsen). Han ville have mig med i en UVM-arbejdsgruppe, som skal udvikle en progressionsplan for idrætselevernes faglige kompetencer. Jeg træder vande i telefonen... jamen, jeg har lige sagt ja til et andet spændende projekt..., har jeg tid? Jeg kan jo bare sige nej. Jeg siger ja. Hvad handler det om? Nytænkning 
af idrætsfaget - tænke forfra og med fokus på progression i elevernes læring over 3 år. Det lyder svært og spændende. Tankerne springer allerede frem til målstregen - vil idrætslærere rundt i landet have overskud til at ændre på deres struktur i årsplan og deres indarbejdede didatik? Vil min egen idrætslærergruppe? Det kører jo for os allerede! Eller gør det? Hvis jeg skal sætte en finger på vores svage punkt, så er det nok lige præcis, at vi ved at vores forløbsplaner skal hænge godt sammen for elevernes skyld, men vores progression styres af tilfældigheder mere end aktive valg. Vores svageste elever i idræt når ikke at lære nok. De har måske brug for at beherske basale idrætskompetencer, før vi er videre i det næste forløb? De opnår ikke fortrolighed med de tekniske og taktiske elementer, og de har grundlæggende svært ved at reflektere over egen læring, fordi deres kropslige erfaringsgrundlag er beskedent. Måske når de kun at miste motivationen? Det skaber ulighed i undervisningen alle 3 år. De dygtige elever lærer hurtigt, og de svageste elever lærer langsomt. Kan vi blive bedre til at strukturere undervisningen, så flere elever lærer mere? Så de samme eller næste samme tekniske og taktiske elementer føres videre fra år til år? Og så er der jo også en masterafhandling fra 2013 (Schiørring og Eriksen), som peger på en ret tankevækkende skævhed i gymnasieelevers opfattelse af idrætsfaget. Undersøgelsen viser, at eleverne ikke er klar over at læring faktisk er målet med idrætsundervisningen. Mange tror, at formålet udelukkende er bevæ-

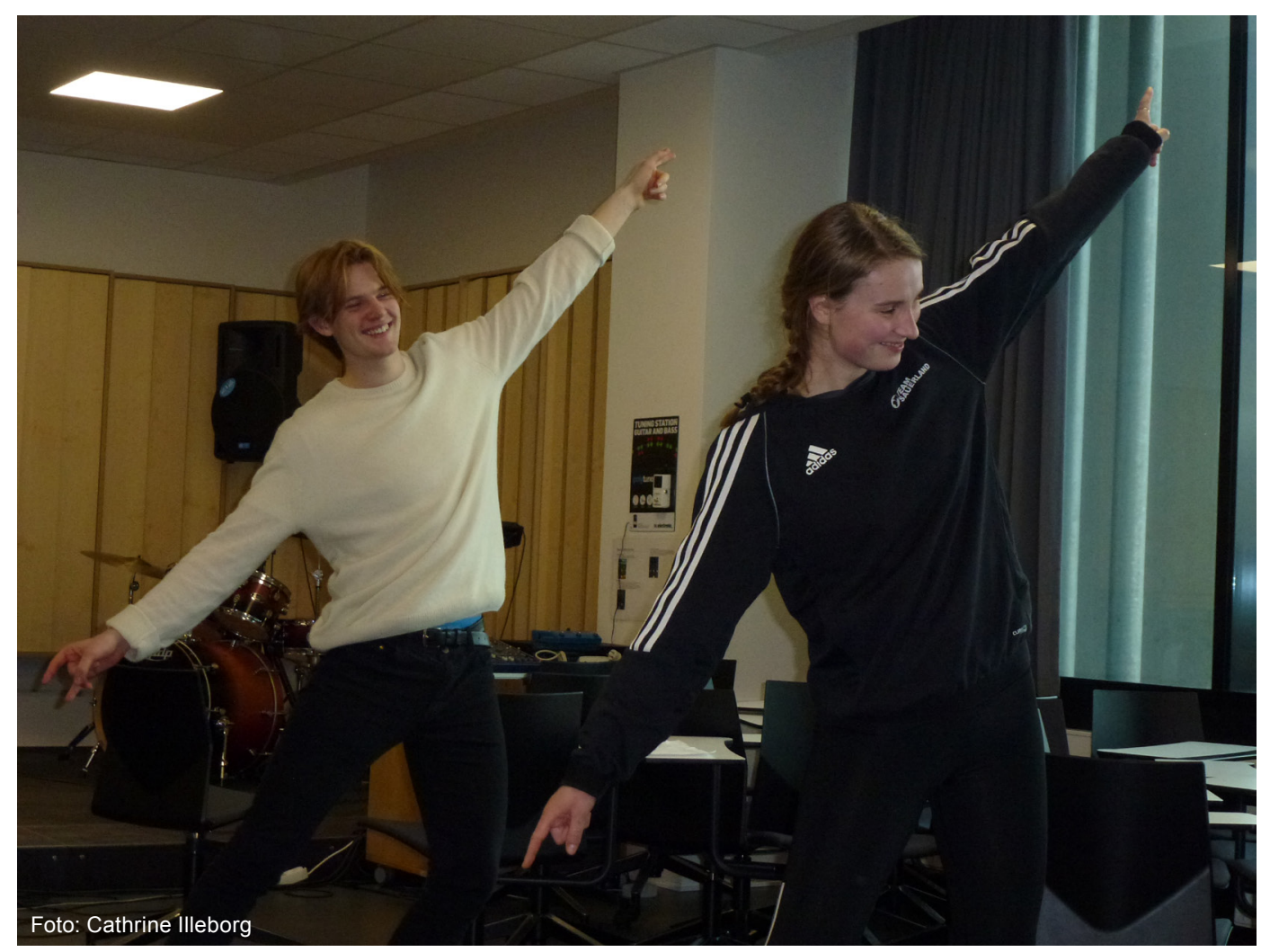


gelse - altså motion. Der kan være god grund til at arbejde med mere synlig læring, for hvis eleverne kan være i tvivl om fagets formål, så er vi idrætslærere enten ret dårlige til at sætte ord på det, vi skal i vores fag - eller også er eleverne dårlige til at lytte og forstå. De har måske fordomme om faget som frikvartersfag, som først skal nedbrydes. Lad os bare komme i gang.

Udfordring2.0 At skide i egen rede. 1. møde i arbejdsgruppen og med fagkonsulenten. Vi skal over nogle måneder tænke den progression i idræt, som udvikler elevernes faglige kompetencer - og vi skal udgive en rapport om kort tid. Hvor skal vi starte? Vi bliver ved med at vende tilbage til, hvor svær en kommende implementeringsproces bliver. Tør vi lægge op til så store forandringer på hjemmebane? Ja, det er faktisk vores opgave at turde stille os ud i det åbne. Jeg bliver selv ved med at vende tilbage til tanken om de svageste elever, som vi ikke rigtig kan nå at lære noget hos os. Ja, kom nu! Det er det, vi skal. Alle elever skal lære mere ved at blive undervist i forløb, som bygger videre på det allerede lærte. Forløbene skal tænkes i forlængelse af hinanden fra starten. Og forløbene skal gerne være lange. Vi bliver derfor nødt til at tænke nyt i forhold til, hvad eleverne skal lære. Vi kan ikke, som nu, planlægge, hvad vi skal LAVE - vælge discipliner og færdighedsområder - men planlægge ud fra hvad eleverne skal LÆRE - hvilke idrætskompetencer, de skal udvikle over de 3 år. Vi ved, at eleverne skal lære noget teknisk, de skal udfordres på deres fysiske kapacitet, lære taktisk forståelse og kunne reflektere over deres praksis og læring med blandt andet teori. Vores nye kompetenceoversigt tager langsomt form. Og ideen om, at eleven skal arbejde med alle de oplistede kompetencer hvert skoleår, bliver den naturlige konsekvens. Oversigten tænkes som styringsredskab til at sikre progression i undervisningen. Den kan styre planlægningen, men efterlader frihedsgrader til valg af indhold i en 3-årig undervisningsplan. Vi diskuterer igen idrætslærerens rolle i forhold til den nye idé. Der lægges jo kraftigt op til, at man planlægger langt frem i tiden for det enkelte hold, hvis ideen om bevidst progression skal holde. Så er det en fantastisk mulighed for, og et godt argument for, at den enkelte idrætslærer følger de samme elever alle 3 år. Den model har vi afprøvet i vores lærergruppe og flere af os er blevet rigtig glade for at etablere elevkontakt i 1.g og kunne følge elevernes læring over 3 år. Men, måske er det en idé, der er urealistisk mange steder? Det kræver et bevidst valg og enighed i idrætslærergruppen om, at dette princip vægtes højt. Væk med supermarkedsmodellen med de valgfri pakker! ? Og skolernes skemalæggere skal være med på at følge progressionsideen til dørs. Lærere skal helst ikke bare skiftes ud på hold fra år til år. Også her har skolerne forskellig praksis. 


\section{Figur 1}

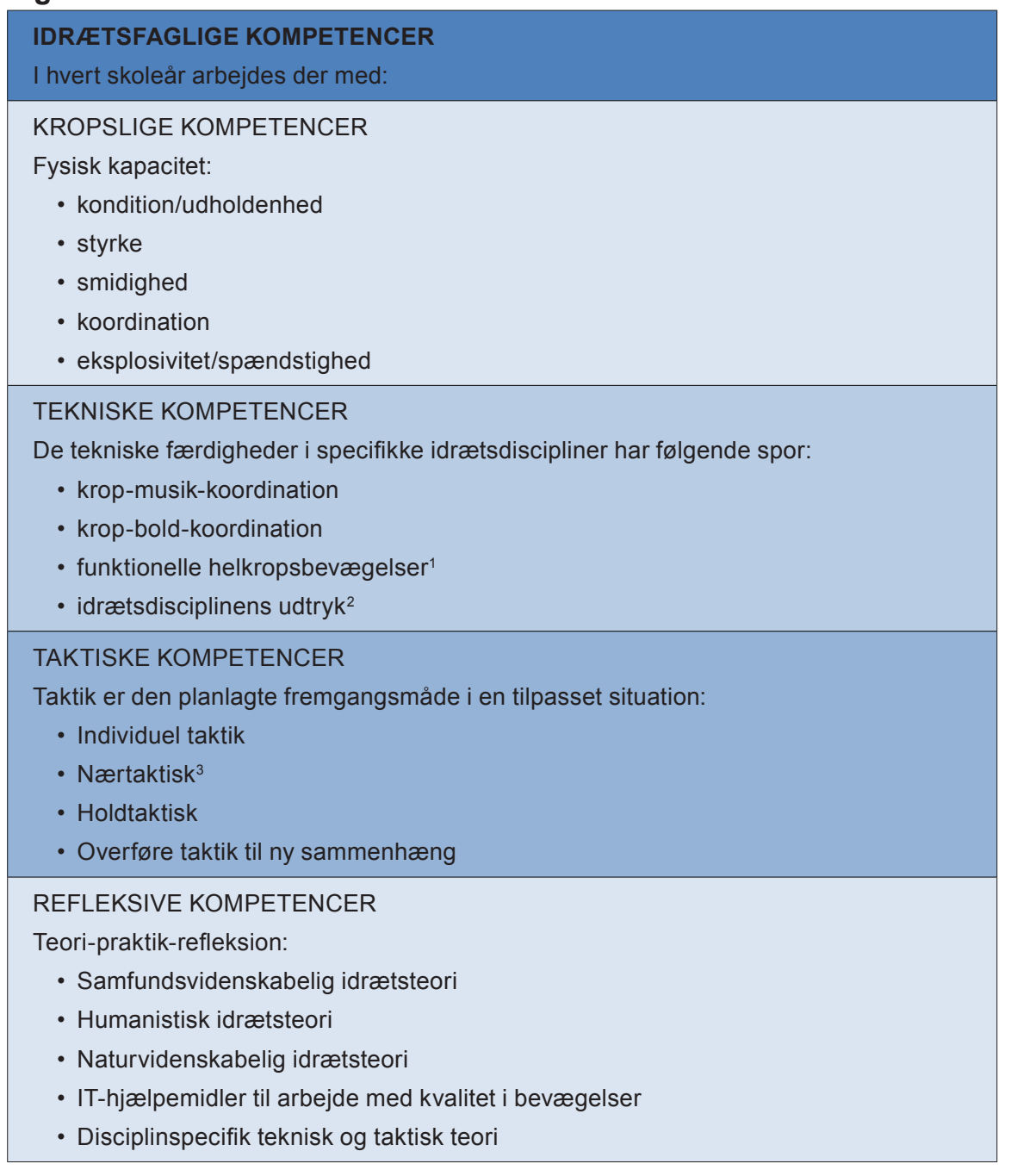

Udfordring3.0. At tale rent. Vi skal formulere os! Hvordan skal det hele forstås? Hvad er begrundelsen for, at denne måde at tænke på kan være byggesten i idrætslærerens planlægning? De spørgsmål fylder meget i gruppens arbejde. En del stykker sushi bliver skyllet ned med sodavand, snakken går, og gang på gang sidder vi tilbage med den samme pointe. Hvis læreren på forhånd har lavet elevernes kompetenceplan med progression over 3 år, kan hun eller han mere bevidst undervise

1 Funktionelle helkropsbevægelser: Målrettede sammensatte og komplekse bevægelser.

2 Idrætsdisciplinens udtryk: Det aspekt af idræt hvor det korrekte kropslige udtryk har betydning for disciplinens udførelse. Det kunne fx være i finter i fodbold, kropsholdningen i vals og grounding i capoeira.

3 Nærtaktisk: Den nærtaktiske kompetence kan der fx arbejdes med i pardans eller badminton mens den individuelle taktik fx kan trænes i 5 km løb, parkour, hip hop. 
eleverne med fokus på læring. Og med et eksempel fra praksis: når man skal planlægge et 3-årigt forløb og fra starten vælger, i hvilket forløb i 1.g, det passer bedst at træne den nærtaktiske kompetence, og i hvilket forløb i 2.g og 3.g samme kompetence skal trænes, så tvinges man til at sætte ord på den læring, man planlægger for eleverne. Det bliver dermed lettere at involvere eleverne i deres læring og få evalueret kompetenceområder i forbindelse med karaktergivning og elevsamtaler. Planlægningsfasen bliver måske længere og kræver næranalyse, men til gengæld får den enkelte underviser overblik over hele det 3-årige forløb og kan italesætte sin progressionstanke for eleverne, at ...fx den nærtaktiske kompetence, der arbejdes med nu... vender vi tilbage til i 2.g, når vi skal arbejde med badminton ...og igen i 3.g, når vi skal arbejde med pardans. Der er altså potentiale for, at både elever og lærere kan få større overblik over, hvor vi vil hen med undervisningen. Det er jo i forvejen svært at sætte ord på det, vi skal lære med kroppen. Så måske kan kompetencerne også blive anvendelige som terminologi, når vi har samtaler om læring?

Udfordring4.0. Det stopper ikke. Da vi først kom i gang med at arbejde med progression og kompetencer, fulgte en sprogproblematik os som en sort skygge. Beskrivelse af progression i fagene kræver taksonomi. Vi skal have et sprog for, hvornår en elev mestrer en idrætsfærdighed på et bestemt niveau. Og hvordan kan vi bruge Blooms taksonomi i idræt, når den bygger på kognitiv erkendelse? Vores fag er praktisk. Vi kan ikke diskutere et baggerslag. Altså det kan vi jo godt. Men, en elev lærer ikke at modtage en hård serv med et baggerslag ved at diskutere eller perspektivere et baggerslag. Eleven har forstået baggerslaget, hvis hun eller han kan udføre det teknisk korrekt og på det højeste taksonomiske niveau, hvis det også kan lade sig gøre i en kamp, hvor uforudsigelighed og holdtaktik er en faktor. Vi har akut brug for at anvende en anden taksonomi end Blooms. Og vi skal anvende den, for at blive bedre til at kommunikere med elever og vores kolleger om elevernes læring og faglige udvikling. Vi tog udfordringen op og afprøvede SOLOtaksonomien, som efter næranalyse viste sig at være brugbar. Måske kan det blive lettere at sætte ord på elevens niveau i konkrete praktiske færdigheder, hvis eleverne også kender til de 5 kompleksitetsnivauer - bare omsat til de taktiske og tekniske begreber inden for den enkelte idrætsfaglige emne? Det har i hvert fald vist sig i de teoretiske fag, at eleverne er blevet bevidste om, hvilket taksonomisk niveau forskellige besvarelser befinder sig på. Og de vil gerne vide, hvad de bliver bedømt på. Taksonomi viser sig som et godt redskab, hvis det kobles med konkrete eksempler fra undervisningssituationen eller det skriftlige arbejde. Hvordan gør vi så det i idræt, uden at det bliver ord, ord, ord og ingen handling? Morten Eriksen fra arbejdsgruppen tog opgaven med hjem og kom tilbage med SOLO-taksonomien omsat til de 4 kompetenceområder, vi arbejder med, og et gennemskrevet eksempel fra basketball (se model). Det giver rigtig god mening. Vi skal muligvis selv gå i gang med at oversætte til vores forskellige praktiske forløb ude på skolerne? 
Vi taler også i gruppen om, at når vi som lærere bliver bevidste om idrættens kompleksitetsniveauer, giver det større mening at bygge ovenpå det, eleven lærer fra år til år. Vi er enige om, at det er bedre at lære noget godt og grundigt og mestre det (relationelt eller måske endda abstrakt) end altid kun nå til at være uni-struktureret. Og så skulle starte forfra på noget nyt og svært. Er det ikke i modstrid med læreplanen for faget? Eleverne skal gennem alsidig idrætsundervisning opleve glæden ved at bevæge sig, således at de motiveres til fortsat fysisk aktivitet (læreplanen, idræt c)

Måske er det på tide at sige, at alsidighedsprincippet må sidestilles med progressionsprincippet? På tide, at alle elever skal tilbydes en mulighed for reelt at lære at beherske noget med kroppen - gennem mange gentagelser. At blive så god til noget, at man kan tage den oplevelse af at have gennemgået en lang læringsproces med sig til andre læringssituationer - og med ud i livet efter gymnasiet. Det er en svær og kompleks værdidiskussion.

\section{Figur 2}

\begin{tabular}{|c|c|c|}
\hline SOLO & $\begin{array}{l}\text { Diagram inde i } \\
\text { hovedet }\end{array}$ & De fire kompetenceområder \\
\hline $\begin{array}{l}\text { Præ-struktureret } \\
\text { Opgaven gribes ikke hensigts- } \\
\text { mæssigt an. } \\
\text { Eleven arbejder med irrelevante } \\
\text { aspekter og/eller arbejder forkert } \\
\text { med relevante aspekter. } \\
\text { Karakter: }-3 \text { og } 00\end{array}$ & $?$ & $\begin{array}{l}\text { Eleven er inaktiv eller udførelsen præges af tom per- } \\
\text { formance - dvs. fysisk aktivitet uden et fagligt indhold. } \\
\text { De teoretiske refleksioner er præget af hverdags- } \\
\text { sprog, og eleven viser ikke alsidighed. }\end{array}$ \\
\hline $\begin{array}{l}\text { Uni-struktureret } \\
\text { Beherskelse af enkeltdele. } \\
\text { Læringsudbyttet viser enkle for- } \\
\text { bindelser, men uden registrering } \\
\text { af væsentlighed. } \\
\text { Karakter: } 02\end{array}$ & $\begin{array}{ll} & * \\
& * \\
* & * \\
& *\end{array}$ & $\begin{array}{l}\text { Eleven evner enkle tekniske færdigheder på basalt } \\
\text { niveau og kan kun indgå i helheden vha. tilfældig brug } \\
\text { af disse færdigheder. Derfor mangelfuld deltagelse i } \\
\text { helheden, da manglende kropslige-, tekniske- og/eller } \\
\text { taktiske kompetencer lukker for deltagelsen. } \\
\text { Enkelte centrale teoretiske refleksioner anvendes og } \\
\text { eleven viser alsidighed på tilstrækkelig vis. }\end{array}$ \\
\hline $\begin{array}{l}\text { Multistruktureret } \\
\text { Beherskelse af mangfoldighed. } \\
\text { Læringsudbyttet viser, at der } \\
\text { skabes forbindelse, men at der } \\
\text { mangler forståelse af den over- } \\
\text { ordnede sammenhæng. } \\
\text { Karakter: } 4 \text { eller } 7\end{array}$ & 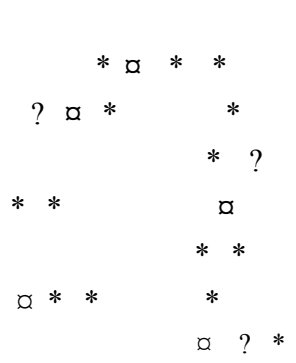 & $\begin{array}{l}\text { Eleven evner flere tekniske færdigheder og viser } \\
\text { variationer af den enkle teknik. Eleven kan indgå i hel- } \\
\text { heden vha. af færdighederne inkl. variationer. Eleven } \\
\text { viser forståelse for taktiske kompetencer, men pga. de } \\
\text { manglende kropslige-, tekniske- og/eller taktiske kom- } \\
\text { petencer drages der forkerte, forhastede konklusioner } \\
\text { i den samlede udførelse. } \\
\text { Centrale teoretiske refleksioner anvendes og kan } \\
\text { generaliseres delvist. Eleven viser alsidighed på } \\
\text { tilfredsstillende vis. }\end{array}$ \\
\hline $\begin{array}{l}\text { Relationelt } \\
\text { Beherskelse af overgribende } \\
\text { sammenhænge. } \\
\text { Læringsudbyttet viser, at der } \\
\text { skabes komplette forbindelser og } \\
\text { syntese af disse i forhold til den } \\
\text { overordnede sammenhæng. } \\
\text { Karakter: } 10\end{array}$ & $\int_{\infty}^{*} * *$ & $\begin{array}{l}\text { Eleven evner relevante tekniske færdigheder og } \\
\text { bidrager til helhedsudførelsen og viser derved } \\
\text { taktisk overblik. De kropslige kompetencer er ikke } \\
\text { en begrænsning. Eleven er dog mangelfuld i forhold } \\
\text { til progressionssammenhænge og anvendelse af } \\
\text { generaliseringer. } \\
\text { Centrale teoretiske refleksioner anvendes og kan } \\
\text { generaliseres. Eleven viser alsidighed på fortrinlig vis. }\end{array}$ \\
\hline
\end{tabular}




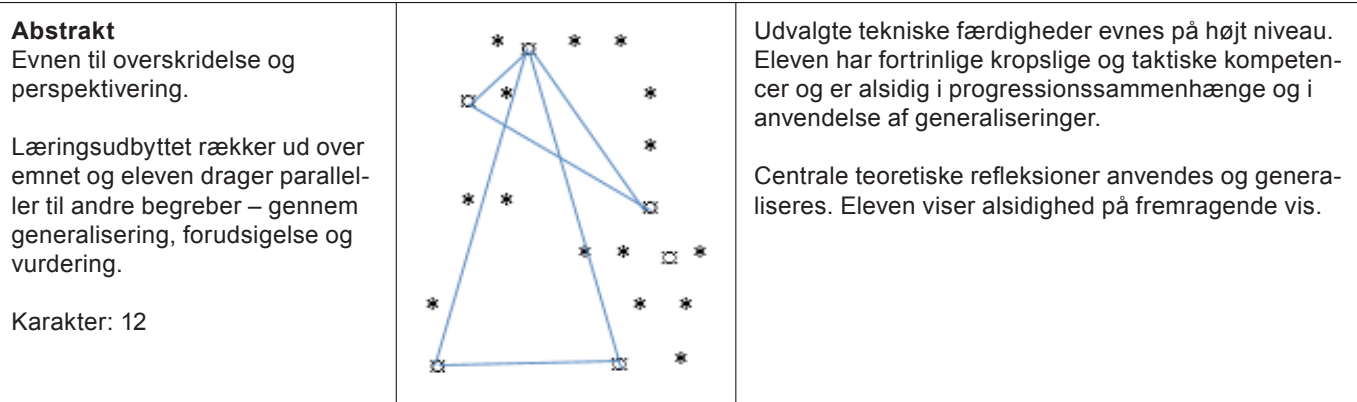

Figur 2: SOLO og idrct. Indholdet i første kolonne er citeret fra Laringsmål og taksonomiske redskaber, Dafolo 2015.

\section{Figur 3}

\section{Eksemplificeret med et basketballforløb}

Nedenstående skema (Rubric-skema) er udskrivningen af SOLO-taksonomien i relation til specifikke idrætsfærdigheder. I rækkerne fremgår de taktiske og forskellige tekniske evalueringskriterier inden for basketballforløbet. Kolonnerne er formuleringer af, i hvor stor grad eleven opfylder de faglige mål.

(Basketballforløb med fokus på basale tekniske og taktiske færdigheder)

\begin{tabular}{|c|c|c|c|c|}
\hline & Begyndelse & $\begin{array}{l}\text { Tilnærmelse til faglige } \\
\text { mål }\end{array}$ & $\begin{array}{l}\text { Beherskelse af faglige } \\
\text { mål }\end{array}$ & $\begin{array}{l}\text { Opnåelse/Overstigelse } \\
\text { af faglige mål }\end{array}$ \\
\hline Dribling & $\begin{array}{l}\text { Sjældent i stand til } \\
\text { at kontrollere bolden } \\
\text { og holde passende } \\
\text { hastighed }\end{array}$ & $\begin{array}{l}\text { Af og til i stand til at } \\
\text { kontrollere bolden } \\
\text { og holde passende } \\
\text { hastighed }\end{array}$ & $\begin{array}{l}\text { Tit i stand til at kontrol- } \\
\text { lere bolden og holde } \\
\text { passende hastighed }\end{array}$ & $\begin{array}{l}\text { Oftest i stand til at kon- } \\
\text { trollere bolden og holde } \\
\text { passende hastighed }\end{array}$ \\
\hline Aflevering & $\begin{array}{l}\text { Sjældent i stand til at } \\
\text { aflevere med kontrol i } \\
\text { retning og fart }\end{array}$ & $\begin{array}{l}\text { Af og til i stand til at } \\
\text { aflevere med kontrol i } \\
\text { retning og fart }\end{array}$ & $\begin{array}{l}\text { Tit i stand til at aflevere } \\
\text { med kontrol i retning } \\
\text { og fart }\end{array}$ & $\begin{array}{l}\text { Oftest i stand til at } \\
\text { aflevere med kontrol i } \\
\text { retning og fart }\end{array}$ \\
\hline Modtagning & $\begin{array}{l}\text { Sjældent i stand til at } \\
\text { komme i position til at } \\
\text { modtage og kontrollere } \\
\text { bolden }\end{array}$ & $\begin{array}{l}\text { Af og til i stand til at } \\
\text { komme i position til at } \\
\text { modtage og kontrollere } \\
\text { bolden }\end{array}$ & $\begin{array}{l}\text { Tit i stand til at komme } \\
\text { i position til at modtage } \\
\text { og kontrollere bolden }\end{array}$ & $\begin{array}{l}\text { Oftest i stand til at } \\
\text { komme i position til at } \\
\text { modtage og kontrollere } \\
\text { bolden }\end{array}$ \\
\hline $\begin{array}{l}\text { Taktiske } \\
\text { kompeten- } \\
\text { cer }\end{array}$ & $\begin{array}{l}\text { Sjældent i stand til at } \\
\text { træffe korrekte valg i } \\
\text { spilsituationer både } \\
\text { individuelt og i forhold } \\
\text { til med- og modspillere. }\end{array}$ & $\begin{array}{l}\text { Af og til i stand til at } \\
\text { træffe korrekte valg i } \\
\text { spilsituationer både } \\
\text { individuelt og i forhold } \\
\text { til med- og modspillere. }\end{array}$ & $\begin{array}{l}\text { Tit i stand til at træffe } \\
\text { korrekte valg i spilsitu- } \\
\text { ationer både individuelt } \\
\text { og i forhold til med- og } \\
\text { modspillere. }\end{array}$ & $\begin{array}{l}\text { Oftest i stand til at } \\
\text { træffe korrekte valg i } \\
\text { spilsituationer både } \\
\text { individuelt og i forhold } \\
\text { til med- og modspillere. }\end{array}$ \\
\hline
\end{tabular}

Udfordring5.0. Rapport afleveret, hvad nu? November 2015. Nu skal vi til at have progression på dagsordenen rundt om på skolerne, men livet som idrætslærer tager en akut drejning. Besparelser varsles i hele gymnasiesektoren. Idrætsfaget er på sigtekornet. Hvorfor? Har vores fag lavere status end de andre fag? Kan ledelserne ikke se, at det kræver mindre hold, hvis vi skal lave god og forsvarlig undervisning? At der er tale om en anderledes læringssituation, når eleven skal lære det faglige gennem kroppen og ikke gennem bøger og artikler, som i boglige fag. Vi skal 
jo netop undervise så den enkelte elev udnytter sit læringspotentiale - og det kræver større elevkontakt at undervise i idræt. Mit hoved koger over. Væk er tanker om at implementere kompetenceplanlægning for bevidst progression. Vores skole vil i nær fremtid skære ned til 1 idrætslærer pr klasse. Jeg klamrer mig til håbet og kampen for vores fags status på skolen. Mister vi ikke eleverne i svinget? Bliver faget ikke reduceret til netop den tendens masterafhandlingen om motivation advarer mod, et fag uden bevidsthed om læring? At idrætsundervisning vil blive igangsætning af aktiviteter, fordi fokuseret læringsorienteret undervisning for alle elevtyper bliver utopisk. Er progression i idrætsundervisningen også utopisk? Det er svært at bevare optimismen. Kan vi holde til at skulle stå overfor eleverne og være tvunget til at levere en ringere undervisning? Jeg forsøger at se frem i tiden til når vandene falder til ro igen. Vil der blive brug for arbejdsgruppens rapport om progression i idrætsfaget? Får vi kræfter til at udvikle vores faglige praksis? Jeg håber det.

Karakteristik2.0. Juni 2016. Sidder og forbereder mig til kommende idrætslærermøde. Læser i vores elektroniske konference, tænker over, hvad der er sket siden sidst, og hvad vi har på dagsordenen til vores møde. Ingen af kollegerne har mistet modet, virker det til. Der er planer om OL-temadag, der tænkes på nye gode tiltag for eleverne. Der har været afholdt årsprøver for enkelte elever med for stort fravær i enkelte forløb til at lærerne kunne bedømme deres standpunkt. Der er altså kun tegn på, at idrætslærergruppen er stærk og sund. At det stadig er undervisning med fokus på høj faglighed, elevernes læring og refleksion over undervisning, der er i højsæde. OK, jeg må overvinde min modstand og sætte progressionsprojektet på dagsordenen. Vi må se, om der er energi til at tænke anderledes. Jeg sender rapporten ind i konferencen nu. Og laver min egen progressionsplan færdig for 1.s. Det skal køre videre for os - for elevernes skyld!

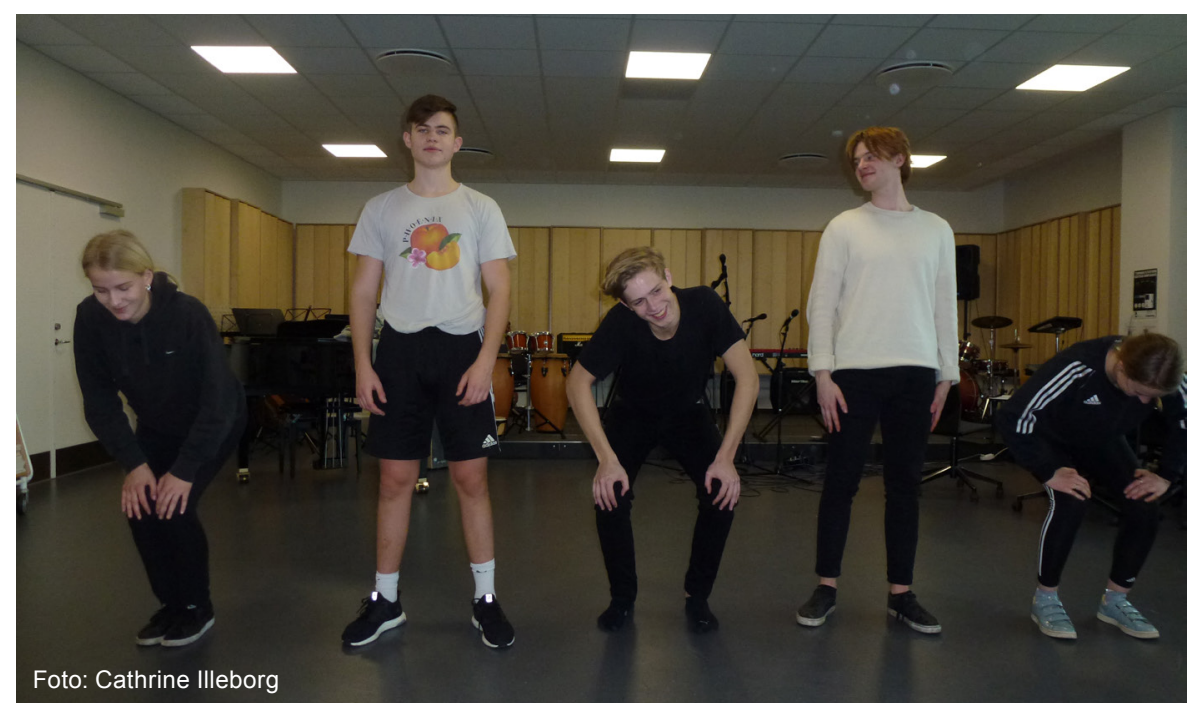

